\title{
Double-blind Trial of Propranolol (Inderal) in Angina of Effort
}

\author{
S. C. SRIVASTAVA,* M.D., M.R.C.P.ED. ; H. A. DEWAR, † M.D., F.R.C.P. ; \\ D. J. NEWELL, $\ddagger$ M.A., PH.D.
}

\section{Brit. med. F., 1964, 2, 724-725}

Blockade of adrenergic beta-receptors has a possible application in the management of angina of effort, presumably through reduction of exercise-induced tachycardia and thereby of total cardiac work. A clinical trial with pronethalol has shown encouraging results (Alleyne et al., 1963). Its further use has, however, been limited partly by frequent central-nervous-system side-effects and partly by its carcinogenic action on mice (Paget, 1963).

Propranolol (I.C.I. 45520, Inderal), a newly developed agent with a similar mode of action, has been shown to have a therapeutic effect about 10 times greater than that of pronethalol but without demonstrable carcinogenic potential (Black et al., 1964). The results of its use in a double-blind trial in) cases of angina of effort are reported.

\section{Material and Methods}

Twenty-two patients (15 males and 7 females) were selected for the trial. They all had classical angina of effort, occurring several times a day. The history of their angina varied considerably, ranging from three months to 15 years, with an average of three years, but the severity of their symptoms had remained almost unchanged for at least two months before the start of the trial. Ten patients had sustained previous myocardial infarction. All 22 subjects had electrocardiographic evidence of ischaemic heart disease at rest.

Patients attended the hospital at the beginning of the trial and at the end of two successive periods of three weeks each, and were seen by the same member of the team. Each patient was asked to keep a " progress card" and to note on it at the end of each day the number of anginal attacks, the number of TNT tablets taken to relieve them, and whether the pain that day had been the same as usual, worse, better, or absent. At each attendance the patients were examined and their general well-being, body weight, heart rate, and blood-pressure recorded. They also had electrocardiograms taken and specimens were collected for urine analysis, white-cell count, and haematocrit, and for liver-function tests, including serum transaminase and paper electrophoresis. At the interview concluding each threeweek period of treatment they were asked to give their own opinion of the effect of the treatment upon their angina and were questioned about any side-effects.

The double-blind trial was arranged so that the patients received the drug and placebo tablets for a three-week period each in a random order. The drug was prescribed in $10-\mathrm{mg}$. tablets in a standard dosage of one tablet three times a day for three days and thereafter increased to two tablets three times daily. If side-effects developed the patients had instructions not to discontinue the tablets but to reduce the dose to four tablets a day and to seek an early interview. This' regimen of dosage was calculated from earlier experience with

\footnotetext{
* Senior Registrar in Medicine, Royal Victoria Infirmary and the University of Newcastle upon Tyne, Newcastle upon Tyne.

† Physician and Cardiologist, Royal Victoria Infirmary and the University of Newcastle upon Tyne, Newcastle upon Tyne.

$\ddagger$ Reader in Biostatistics, Royal Victoria Infirmary and the University of Newcastle upon Tyne, Newcastle upon Tyne.
}

pronethalol, which had been found effective in a daily dose of $300-400 \mathrm{mg}$. The corresponding dose of $30-40 \mathrm{mg}$. of propranolol could have been employed, but a slightly higher dose was preferred in order to assess the frequency and nature of possible side-effects in a short-term trial. A similar plan was used for the placebo. Since the tablets tasted differently, the patients were told in advance that they would be receiving two drugs with a slightly different composition and that their co-operation was needed to find out which of the two was the more effective.

\section{Results}

Twenty patients completed the trial satisfactorily and provided the results for analysis. Of the original 22 , one patient defaulted in the first stage of the trial, and another complained of increasingly severe angina during the fifth week of the trial (while on the placebo) and had to be admitted to hospital. Moreover, he had kept inaccurate records of his symptoms, and, since there was some doubt about the true nature of them, it was decided to omit him from the final assessment. Of the remaining 20 patients all except two continued with their prescribed dose of six tablets a day. These two patients reduced the daily dose of propranolol because of constant dizziness and subsequently lost this symptom. The same side-effect occurred in three other patients, but they did not consider it necessary to reduce the dosage. One of them also suffered from mild nausea and anorexia. However, in these patients as well the symptoms mentioned disappeared when the dosage was reduced at the completion of the trial. No effect on white-cell count, urine composition, or liver-function tests was found in any of the patients after the three weeks' treatment. Similarly, there was no change in heart rate, blood-pressure, or electrocardiograms.

In view of the smaller dose at the beginning of each of the two courses of treatment, and in order to prevent possible "carry-over" effects from one course to the other, the analysis of the "progress cards" has been restricted to the results

\begin{tabular}{|c|c|c|c|c|}
\hline \multirow{2}{*}{ Patients } & \multicolumn{2}{|c|}{ No. of Attacks in 14-day Period } & \multicolumn{2}{|c|}{ Patients' General Assessments* } \\
\hline & Propranolol & Placebo & Propranolol & Placebo \\
\hline $\begin{array}{r}1 \\
2 \\
3 \\
4 \\
5 \\
6 \\
7 \\
8 \\
9 \\
10 \\
11 \\
12 \\
13 \\
14 \\
15 \\
16 \\
17 \\
18 \\
19 \\
20\end{array}$ & $\begin{array}{r}0 \\
2 \\
88 \\
300 \\
10 \\
0 \\
5 \\
5 \\
5 \\
27 \\
4 \\
6 \\
9 \\
10 \\
40 \\
74 \\
17 \\
30 \\
8 \\
70\end{array}$ & $\begin{array}{r}0 \\
99 \\
129 \\
350 \\
28 \\
10 \\
17 \\
3 \\
4 \\
2 \\
17 \\
40 \\
25 \\
22 \\
9 \\
58 \\
26 \\
27 \\
23 \\
66\end{array}$ & $\begin{array}{r}+3 \\
+3 \\
0 \\
0 \\
+2 \\
+3 \\
+2 \\
+2 \\
+2 \\
+1 \\
+2 \\
+2 \\
+3 \\
+2 \\
-1 \\
0 \\
+1 \\
0 \\
+2 \\
0\end{array}$ & $\begin{array}{r}+3 \\
+1 \\
-1 \\
0 \\
+1 \\
+1 \\
0 \\
+2 \\
+2 \\
+3 \\
0 \\
0 \\
+1 \\
0 \\
+2 \\
0 \\
0 \\
0 \\
0 \\
0\end{array}$ \\
\hline
\end{tabular}

* See Table II. 
obtained in the final 14 days of each 21-day period. The patients' own general assessment of each treatment is based upon the whole 21-day periods and scored on a five-point scale in the following way: -1 worsening of the angina $;+1,+2$, and +3 indicating slight, moderate, and marked improvement respectively; and 0 showing that the condition had remained unchanged when compared with that before the start of the trial. The results are summarized in Tables I and II.

TABLE II.-Summarized Results and Statistical Analysis of Trial

\begin{tabular}{|c|c|c|c|c|c|}
\hline \multicolumn{2}{|c|}{ Criterion } & \multirow{2}{*}{$\mid$\begin{tabular}{c|} 
Propranolol \\
$4 \cdot 40$ \\
$0-14$
\end{tabular}} & \multirow{2}{*}{$\begin{array}{c}\text { Placebo } \\
\begin{array}{l}3.55 \\
0-14\end{array}\end{array}$} & \multirow{2}{*}{$\begin{array}{l}\text { Difference } \\
0 \cdot 85 \pm 1 \cdot 08 \\
-11-+10\end{array}$} & \multirow{2}{*}{$\frac{t-\text { Value }}{0.8 \mathrm{NS}}$} \\
\hline Days pain free & $\cdots\left\{\begin{array}{l}\text { mean } \\
\text { range }\end{array}\right.$ & & & & \\
\hline No. of attacks & $\cdots\left\{\begin{array}{l}\text { mean } \\
\text { range }\end{array}\right.$ & $\begin{array}{l}35 \cdot 5 \\
0-300\end{array}$ & $\begin{array}{l}43 \cdot 3 \\
0-350\end{array}$ & $\begin{array}{c}-7 \cdot 8 \pm 4 \cdot 4 \\
-50-+31\end{array}$ & $\begin{array}{c}1.74 \\
0.1>\mathrm{P} \\
>0.05 \mathrm{NS}\end{array}$ \\
\hline TNT tablets & $\ldots\left\{\begin{array}{l}\text { mean } \\
\text { range }\end{array}\right.$ & $\begin{array}{l}26 \cdot 3 \\
0-89\end{array}$ & $\begin{array}{l}29 \cdot 1 \\
0-129\end{array}$ & $\begin{array}{l}-2 \cdot 8 \pm 5 \cdot 4 \\
-41-+62\end{array}$ & $0.5 \mathrm{NS}$ \\
\hline \multirow{2}{*}{\multicolumn{2}{|c|}{$\begin{array}{l}\text { Average No. of days }\left\{\begin{array}{l}\text { better } \\
\text { same } \\
\text { worse }\end{array}\right. \\
\text { Patients' general assessments } \\
\text { of angina }\end{array}$}} & $\begin{array}{l}9 \cdot 1 \\
3 \cdot 7 \\
1 \cdot 3\end{array}$ & $\begin{array}{l}7.5 \\
5 \cdot 1 \\
1.5\end{array}$ & & \\
\hline & & +1.35 & +0.75 & $+0.60 \pm 0.37$ & $P>0.1 \mathrm{NS}$ \\
\hline
\end{tabular}
* Based upon the following five-point scale for the full 21-day periods: Worse $=$
-1 , No change $=0$, Slight improvement $=+1$, Moderate improvement $=+2$, Marked improvement $=+3$.

\pm Figures indicate standard errors based on within-patient comparisons.

Values not statistically significant.

Values not statistically significant but near the $5 \%$ or $10 \%$ level of significance are indicated as $\mathbf{P}>0.05$ and $\mathbf{P}>0.1$ respectively.

\section{Discussion}

It will be seen from Table II that, by all the criteria used, the trial failed to show any statistically significant difference between the drug and the placebo, although the reduction in the number of anginal attacks approached a $5 \%$ level of significance in favour of the drug. The patients' own general assessments showed a similar trend. Indeed, if the seven patients who failed to detect any difference between the drug and the placebo are excluded, the analysis reveals that 11 favoured the drug and only two the placebo.

The number of attacks of angina in the 14-day records varied considerably from patient to patient, and Table I shows that those patients with the largest number of attacks (Nos. 3, 4, 16, and 20, all of whom had more than 50 attacks per 14-day period) derived no benefit at all. These were all cases with angina of long standing, and it is possible that such cases are particularly resistant to this therapy.

Propranolol appears to cause fewer side-effects than pronethalol, and when they occur they respond easily to a reduction in the dose. Whether better results could be obtained with higher doses of propranolol has not been explored in this trial, but the limiting factor in dosage is likely to be not so much toxicity as the tendency of beta-adrenergic blocking compounds to induce circulatory failure by excessive weakening of the force of contraction of heart muscle. Further observations on safe dosage are probably still needed.

It is concluded that the drug is of some value in the treatment of angina except perhaps in chronic severe cases, and a more extended trial would be fully justified.

\section{Summary}

A double-blind trial has been carried out with propranolol (I.C.I. 45520, Inderal) on 20 patients suffering from angina of effort. Although favourable results in this small series did not achieve statistical significance, they showed sufficient promise to justify a more extended trial. Symptomatic side-effects were few and transient, and no toxic effects on the urine, blood count, or liver-function were noted.

Our thanks are due to Mr. H. Poole and his staff of the Pharmacy Department of the Royal Victoria Infirmary for their help in the trial, to the patients who took part in it, and to I.C.I. Pharmaceuticals Ltd. for the supply of the tablets used.

\section{REFERENCES}

Alleyne, G. A. O., Dickinson, C. J., Dornhorst, A. C., Fulton, R. M. Green, K. G., Hill, I. D., Hurst, P., Laurence, D. R., Pilkington, T., Prichard, B. N. C., Robinson, B., and Rosenheim, M. L. (1963). Brit. med. $7 ., 2,1226$.

Black, J. W., Crowther, A. F., Shanks, R. G., Smith, L. H., and Dornhorst, A. C. (1964). Lancet, 1, 1080.

\title{
Use of Propranolol (Inderal) in Treatment of Hypertension
}

\author{
B. N. C. PRICHARD,* M.SC., M.B., B.S. ; P. M. S. GILLAM, † M.B., M.R.C.P.
}

Pronethalol has a hypotensive action in man when given orally over a period of three months, though no effect was seen after acute intravenous injection. In addition, short-term administration in a double-blind trial of pronethalol in angina pectoris (Prichard, Dickinson, Alleyne, Hurst, Hill, Rosenheim, and Laurence, 1963) produced a small but significant hypotensive effect (Prichard, 1964). Fifteen patients were given pronethalol for three months ; they showed an average fall of supine bloodpressure of $33 / 23 \mathrm{~mm}$. $\mathrm{Hg}$, standing $27 / 16 \mathrm{~mm}$. Hg. This hypotensive action of pronethalol was not further investigated in view of its tumour-producing action in mice (Paget, 1963).

The animal pharmacology of pronethalol was reported by Black and Stephenson (1962). It was the first specific

\footnotetext{
* Lecturer in Pharmacology and Therapeutics, Medical Unit, University College Hospital Medical School, London.

† Formerly Senior Registrar. Medical Unit, University College Hospital now Senior Registrar, Whittington Hospital, London.
}

adrenergic beta-receptor-blocking drug, blocking the increased rate and force of contraction of the heart and relaxation of smooth muscle that result from the administration of adrenaline or isoprenaline. The classical adrenergic blocking drugs, such as ergot and phenoxybenzamine, block the alpha effects of adrenaline and noradrenaline, preventing the vasoconstriction seen in certain vascular sites. Pronethalol has no such action and the effect in man is consistent with beta-receptor blockade. It abolishes the dilatation of the forearm blood-vessels following intra-arterial isoprenaline and it alters the response to intravenous adrenaline so that it resembles that of noradrenaline (Dornhorst and Robinson, 1962). It reduces the reflex tachycardia during Valsalva's manœuvre and diminishes the overshoot that follows the release of effort (Prichard, 1964).

Black, Crowther, Shanks, Smith, and Dornhorst (1964) briefly described the pharmacology of the closely related drug propranolol (I.C.I. 45,520, Inderal). It was reported to have 